\title{
Production and Characterisation of Briquettes from Carbonised Cocoa Pod Husk and Sawdust
}

\author{
Prince Ofori, Osei Akoto \\ Kwame Nkrumah University of Science and Technology, Kumasi, Ghana \\ Email: kofiprince89@yahoo.com,wofakmann@yahoo.com
}

How to cite this paper: Ofori, P. and Akoto, O. (2020) Production and Characterisation of Briquettes from Carbonised Cocoa Pod Husk and Sawdust. Open Access Library Journal, 7: e6029. https://doi.org/10.4236/oalib.1106029

Received: December 26, 2019

Accepted: February 25, 2020

Published: February 28, 2020

Copyright $\odot 2020$ by author(s) and Open Access Library Inc.

This work is licensed under the Creative Commons Attribution International License (CC BY 4.0).

http://creativecommons.org/licenses/by/4.0/

(c) (i) Open Access

\begin{abstract}
The demand for wood fuels in rural and some urban areas of Ghana keeps on increasing which could lead to forest degradation. The present study sought to produce and characterise briquette made from cocoa pod husk and a mixed sample which comprised of a mixture of cocoa pod husk and sawdust as an alternative source of fuel to reduce the pressure on wood fuels. Simple methods were used to produce the briquette for the study. The physico-chemical properties of the briquettes were conducted at the Kwame Nkrumah University of Science and Technology (KNUST) where the proximate analysis, ultimate analysis and calorific value of the briquettes were analysed and compared to the controlled sample charcoal produced from "Amire" species ( Terminalia ivorensis) using a completely randomized design (CRD) with 3 replications. A survey was also conducted to determine the usability of the briquettes using purposive sampling technique where sixty (60) respondents were given samples of the two different kinds of briquettes produced to use. Results obtained from the ultimate and proximate analysis showed that there were significant differences among the treatments $(\mathrm{P}<$ 0.05). Results obtained from the calorific value showed that the mixed briquette $(23.6 \mathrm{MJ} / \mathrm{Kg})$ produced significantly $(\mathrm{P}<0.05)$ the highest amount of heat followed by the controlled charcoal $(18.5 \mathrm{MJ} / \mathrm{Kg})$ and carbonised cocoa pod husk briquette $(16.7 \mathrm{MJ} / \mathrm{Kg})$. Outcomes from the survey showed that (97\%) of the respondent used wood fuels for their heating and cooking activities; (98\%) of the respondents were ready to use the new briquettes produced if it is made available. From the results obtained, it could be concluded that the briquettes produced from cocoa pod husk and sawdust could help reduce the pressure on wood fuels, reduce deforestation and also provide cleaner fuel for cooking.
\end{abstract}

\section{Subject Areas}

Agricultural Engineering, Environmental Sciences 


\section{Keywords}

Cocoa Pod Husk

\section{Introduction}

The rapid growth in industrialisation both in developed and developing countries has resulted in an increase in the demand and consumption of energy globally [1]. Traditionally, energy sources used for domestic activities such as cooking in most developing countries have been wood fuels which comprise twigs, firewood and charcoal [2]. The predominant use of fossil fuels has contributed immensely to climate change which has resulted in the search for alternative sources of sustainable energy which are ecologically friendly and also renewable such as biomass [3].

One of the most promising renewable energy sources for replacing fuel wood in Ghana is other forms of biomass which represent great opportunity as feedstocks for bioenergy due to their availability in substantial quantities as waste [4]. Biomass waste from agricultural residues such as corn stalk, rice husk, palm kernel shells, sawdust, cotton stalk, cocoa pod, groundnut husk and coconut husk are abundant in Ghana and have served as alternative fuel for cooking [3]. As a result of the bulkiness and nuisance these waste can cause to the environment, converting such waste materials into biofuels could help to reduce landfill disposal volume and also reduce pollution [5]. The utilisation of biomass residues in their natural form as bioenergy is quite challenging due to certain characteristics that biomass possess in their natural state including high moisture content, low heat emission and discharge of smoke during burning [6]. One best solution to these challenges that biomass residues possess is the use of briquetting technology which adds value to biomass fuels and also improves its heat value [7].

The Ghana Living Standards Survey [8] reported that about three-quarters $(74.8 \%)$ of households in rural areas use wood fuel which comprises charcoal and firewood. This report reveals that charcoal is the most preferred source for heating in most lifestyles in Ghana. Even though charcoal is perceived to be a cheap energy, it provides a source of income for many people living in rural and urban settings, but its intensive use has been detrimental to Ghana's forest reserve and the nation's total environment.

The overexploitation of the forest reserve for charcoal production, firewood and furniture in recent years has caused a reduction of Ghana's forest cover at an estimated rate of $3 \%$ per year [9]. Report from Cocoa Barometer [10] also revealed that increasing acreages of cocoa farms has been one of the major factors contributing to deforestation in protected areas in Ghana. However, Ghana's economy is largely driven by agriculture which accounts for large volumes of agricultural residue which is underutilised for any beneficial purpose [11]. 
Cocoa tends to be the main important agricultural commodity in Ghana generating about $\$ 2$ billion in foreign exchange every year and employs approximately 800,000 families in the cocoa growing region of the country [12]. However, there is more to cocoa than processing only the beans since the beans accounts for $30 \%$ of the fruit and the husk accounting for $70 \%$ which could be used as a feedstock for biomass fuel [13]. With commitments from cocoa producing countries and companies to end deforestation at the 2017 world climate conference held in Bonn, Germany [14], cocoa pods husk could serve as a better alternative as biofuels which can reduce deforestation.

Another form of biomass residue which is abundant and underutilised in the timber industry is sawdust (fine particles). They are mostly heaped on sites just to occupy usable space in many wood processing sites which an alternative use of them as biomass for fuel will have an economic benefit if given the needed attention [15].

In this study, attempts are being made to explore the potential of cocoa pod husk as a substitute to wood charcoal and firewood as a source for energy for domestic heating. The aims of this study are to produce and characterize charcoal briquette made from cocoa pod husk and sawdust as an alternative source of fuel. The outcome of the study would contribute to existing knowledge in the utilisation of biomass resources in Ghana and also present a valuable data as well as provide alternatives to conventional energy sources.

\section{Materials and Methods}

\subsection{Materials}

About $2000 \mathrm{~kg}$ of freshly harvested cocoa pod husks were collected from a cocoa farm at SefwiHumjibre in the Western Region of Ghana. The cocoa pod husks were cut into pieces and sundried for 7 days. Approximately $200 \mathrm{~kg}$ of sawdust from (Terminalia ivorensis) was collected from a wood processing factory in the same area. Again, $9 \mathrm{~kg}$ of wood charcoal from (Terminalia ivorensis) was also collected from charcoal producers within the study area.

Other auxiliary materials that were used include starch binder, $0.02 \mathrm{~mm}$ wire mesh and a locally fabricated manual metallic compressor.

\subsection{Carbonisation and Treatment of Cocoa Pod Husk and Sawdust}

The dried cocoa pod husks were carbonised using the pit method as described by Aphonse et al. [16] with some slight modification. With this method, a pit was dug and sawdust was used as fuel to carbonise the dried cocoa pod husk. A metallic mesh and aluminum sheet of thickness $0.2 \mathrm{~mm}$ was placed on top of the fire to serve as a barrier between the fire and the dried cocoa pod husk to prevent the husk from smoldering into ashes during the carbonisation process.

After carbonisation, the carbonised cocoa pod husks were ground and sieved with a mesh size of $<2 \mathrm{~mm}$. The sieved ccarbonised cocoa pod husks weighing $400 \mathrm{~kg}$ was mixed with starch gel made from cassava in a ratio of $4 \mathrm{~kg}$ to $1 \mathrm{~L} \mathrm{re-}$ 
peatedly to form a paste. The paste was then pressed using a locally fabricated metallic extrusion briquetting press with pistons of circumference $25 \mathrm{~cm}$ and a height of $4 \mathrm{~cm}$ until all the $400 \mathrm{~kg}$ carbonised cocoa pod husk were used. The briquettes were sundried for three days after pressing.

In making the mixed briquette product, $200 \mathrm{~kg}$ of the (Terminalia ivorensis) sawdust collected from the local sawmill was sieved with a mesh to achieve a particle size of $<2 \mathrm{~mm}$. This was mixed with $200 \mathrm{~kg}$ of the sieved carbonised cocoa pod husks to form a composite mixture. A starch gel of $2 \mathrm{~L}$ was mixed with 4 $\mathrm{kg}$ of the composite mixture repeatedly until the $400 \mathrm{~kg}$ composite mixture was used to produce the briquettes.

\subsection{Laboratory Analysis}

The physicochemical properties of the briquettes were analysed at the Renewable and Natural Resources Laboratory and the Chemical Engineering Laboratory of the Kwame Nkrumah University of Science and Technology, Kumasi, where three samples which comprised of the carbonised cocoa pod husks, the mixed sample and wood charcoal from Terminalia ivorensis were analysed.

Parameters that were considered for the ultimate analysis were nitrogen, carbon, oxygen, hydrogen and sulphur content. Ash, moisture, fixed carbon and volatile matter content were the parameters determined for the proximate analysis. The calorific value for the samples was also determined. The wood charcoal product was used to serve as a standard for comparing all the parameters analysed.

\subsubsection{Carbon Content}

The Walkley-Black method as discussed by Nelson and Sommers [17] was used to determine the carbon content for all the three different products. All the three samples taken to the laboratory were ground using a mortar and piston. The ground samples were sieved with a mesh to get a particle size less than $0.5 \mathrm{~mm}$. Approximately 0.5 grams of the sieved samples was weighed into a $500 \mathrm{~mL}$ Erlenmeyer flask. $10 \mathrm{~mL}$ of $0.17 \mathrm{M}$ dichromate $\left(\mathrm{K}_{2} \mathrm{Cr}_{2} \mathrm{O}_{7}\right)$ solution was added to the sample followed by $20 \mathrm{~mL}$ of concentrated sulphuric acid $\left(\mathrm{H}_{2} \mathrm{SO}_{4}\right)$. The sample was swirled to ensure that the mixture was in contact with all the particles. The flask and the content was allowed to stand for $30 \mathrm{~min}$. Distilled water of $200 \mathrm{~mL}$ and $10 \mathrm{~mL}$ of orthosphosporic acid were added to the sample and cooled. Diphenylamine indicator of $2.0 \mathrm{~mL}$ was added and titrated with $0.5 \mathrm{~N}$ ferrous sulphate solution until a colour change from dark blue to a green indicating end point was attained. The titre values and that of the blank solution were recorded. The formula below was used to calculate the percentage carbon content in the samples as described by [17].

$$
\% C=\frac{M \times(V b l-V s) \times 0.003 \times 1.33 \times 100}{g}
$$

where $M=$ molarity of $\mathrm{FeSO}_{4}, V b I=$ volume of $\mathrm{FeSO}_{4}$ of blank titration, $V s=$ 
volume of $\mathrm{FeSO}_{4}$ of sample titration, $g=$ mass of carbonised sample taken in gram, $0.003=$ milli-equivalent weight of $C$ in grams $(12 / 4000)$ and $1.33=$ correction factor used to convert the wet combustion $C$ value to the true $C$ value since the wet combustion method is about $75 \%$ efficient in estimating $C$ value, (i.e. $100 / 75=1.33$ ).

\subsubsection{Nitrogen Content}

This was determined using Kjedahl digestion and distillation method as described by Bremner and Mulvaney [18]. In this procedure, one (1) g of the sieved sample was weighed into a $500 \mathrm{~mL}$ long-necked Kjeldahl flask. Ten (10) $\mathrm{mL}$ of distilled water was added to the sample and allowed to stand for $10 \mathrm{~min}$ to moisten. One spatula full of Kjeldahl catalyst and ten (10) $\mathrm{mL}$ of concentrated $\mathrm{H}_{2} \mathrm{SO}_{4}$ were added to the sample and digested until the solution became clear. The digested sample was filtered into a $50 \mathrm{~mL}$ volumetric flask. The digested flask was rinsed with distilled water to make up the $50 \mathrm{~mL}$ flask. An alloquent of $10 \mathrm{~mL}$ of digest was transferred by means of pipette into the Kjeldahl distillation apparatus with an addition of $90 \mathrm{~mL}$ distilled water. $20 \mathrm{~mL}$ of $40 \% \mathrm{NaOH}$ was added. The distillate was collected over a $10 \mathrm{~mL}$ of $4 \%$ boric acid and mixed with three (3) drops of indicator in a $500 \mathrm{~mL}$ conical flask for $5 \mathrm{~min}$. Hundred $\mathrm{ml}$ of the distillate was collected. The collected distillate (about $100 \mathrm{~mL}$ ) was titrated with $0.1 \mathrm{~N} \mathrm{HCl}$ until a blue color changes to grey and then suddenly flashes to pink. The nitrogen content was calculated using the formula below [18].

$$
\% N=\frac{(a-b) \times 1.4 \times N \times V}{s}
$$

where $a=$ volume of $\mathrm{HCl}$ used in the sample titration, $b=$ volume of $\mathrm{HCl}$ used in the blank titration, $N=$ Normality of standard $\mathrm{HCl}, v=$ total volume of digest and $s=$ mass of oven dried sample taken for digestion.

\subsubsection{Hydrogen Content}

The hydrogen contents were determined using the method developed by the American Society for Testing and Materials (ASTM-D3178) as described by Adekunle et al. [19]. Two (2) grams of the sample was placed in a platinum crucible and placed into the combustion tube where it was burnt with oxygen at a temperature of $1300^{\circ} \mathrm{C}$. The combustion product of the sample was made to flow over a heated copper oxide, lead chromate and into an absorption train. The copper oxide ensures a complete combustion of the hydrogen in the sample whiles the lead chromate absorbs the oxides of sulphur. The pre weighed absorbers in the absorption train absorbed both water and carbon dioxide. The percentage of hydrogen in the sample was calculated from the increase in weight of the absorbent which was used to collect the water and carbon dioxide. This method was used for all the three samples.

\subsubsection{Sulfur Content}

Sulfur content was determined using a method developed by the American So- 
ciety for Testing and Materials (ASTM-D 3177) as described by Adekunle et al. [19]. One (1) gram of coal sample was put into a porcelain crucible and mixed with $3 \mathrm{~g}$ of Eschka mixture. The mixture was then covered with $1.0 \mathrm{~g}$ of Eschka mixture (a mixture of two part magnesium oxide and one part anhydrous carbonate). The crucibles were then put in a cold muffle furnace and heated gradually to $800^{\circ} \mathrm{C}$ for $60 \mathrm{~min}$. Digestion was carried out in hot water for $45 \mathrm{~min}$. with intermittent stirring. The solution in each beaker was then decanted through a grade 540 Watman filter paper into a $400 \mathrm{~mL}$ beaker. Three (3) drops of methyl orange indicator were added dropwise until colour turned just neutral. One (1) $\mathrm{mL}$ of hydrochloric acid was added, after which $25 \mathrm{ml}$ of potassium sulphate solution was also added. The sample was heated and $10 \mathrm{~mL}$ of $10 \%$ barium chloride solution was gradually added while stirring. The solution was boiled for 30 min. and filtered with grade (42) Watman filter paper after it was cooled down. The trapped residue was washed thoroughly with hot water. The total sulfur content was calculated using the formula below as described by (ASTM-D 3177) for all the three samples.

$$
\% S=\frac{A-B \times 13.738}{C}
$$

where $A=$ mass of barium sulphate from the sample,

$B=$ mass of barium sulphate from the blank,

$C=$ mass of sample.

\subsubsection{Oxygen Content}

The oxygen content was calculated by summing up all the ultimate analysis results which are hydrogen, sulphur, carbon, ash, nitrogen and deducting it from 100. The formula below was used to calculate the oxygen content in the samples as described by Spreight [20] for all the samples:

$\%$ Oxygen $=100-($ Hydrogen + Nitrogen + Sulphur + Carbon + Ash content $) \%$

\subsubsection{Moisture Content}

With reference from Omoniyi and Olorunnisola [21], the moisture content was determined by this procedure. The weight of the crucible was measured and recorded. Five grams of the sample was weighed into the crucible. The sample with the crucible was put in an oven at $105^{\circ} \mathrm{C}$ for $24 \mathrm{~h}$. The sample in the crucibles was cooled and reweighed. This was repeated till a constant weight was obtained.

The moisture content was determined and calculated based on the formula below as described by Omoniyi and Olorunnisola [21] for all the three samples.

$$
\begin{gathered}
(A+B)-A=B \\
(A+B)-(A+C)=B-C=D \\
\text { \%Moisture }=\frac{D}{B} \times 100
\end{gathered}
$$

where $A=$ crucible weight, $B=$ sample weight, $C=$ dry sample weight and $D=$ 
moisture weight.

\subsubsection{Ash Content}

The ash content was determined with reference from Omoniyi and Olorunnisola [21]. With this procedure, five grams of the grounded sample was weighed into a porcelain crucible. The sample with the crucible was put into a furnace for $4 \mathrm{~h}$ at $550^{\circ} \mathrm{C}$. The furnace was allowed to cool below $200^{\circ} \mathrm{C}$ for $20 \mathrm{~min}$. The ash crucible was removed from the furnace, placed in a desiccator to cool, weighed and calculated by the expression below for all the three samples as described by Omoniyi and Olorunnisola [21].

$$
\begin{aligned}
& (A+B)-A=B \\
& (A+C)-A=C \\
& \text { \%Ash }=\frac{C}{B} \times 100
\end{aligned}
$$

where $A=$ crucible weight, $B=$ sample weight and $C=$ ash weight.

\subsubsection{Volatile Matter}

The volatile matter was determined in accordance to international organization for standards 562/1974. With this method $2 \mathrm{~g}$ of the ground sample was weighed and recorded. The ground sample was incinerated in a crucible for 5 minutes at a temperature of $800^{\circ} \mathrm{C}$ and allowed to cool in the desiccator. The weight of the sample after cooling was also measured. The formula below was used to calculate the volatile matter content as described by Omoniyi and Olorunnisola [21] for all the three samples.

$$
\% \text { Volatile Matter Content }=\frac{A-B}{A} \times 100
$$

where $A=$ initial weight and $B=$ final weight.

\subsubsection{Fixed Carbon}

According to Akowuah et al. [3], the fixed carbon is the solid fuel which is left after the volatile matter is distilled off. Fixed carbon content was calculated by adding the percentage moisture content, percentage ash content and percentage volatile matter and deducted from 100 to get the percentage fixed carbon content of the samples. The formula below was used to calculate the fixed carbon content as described by Spreight [20].

$\%$ Fixed carbon $=100-($ moisture content + ash content + volatile matter $)$

\subsubsection{Determination of the Calorific Value}

Calorific value is the quantity of heat that is released by a unit mass of a sample when burned completely with oxygen at a constant volume. For the purpose of this study a Parr 6400 Bomb calorimeter and standard benzoic acid of 26.1912 $\mathrm{MJ} / \mathrm{kg}$ were used to carry the experiment. The calorimeter was turn on and with the oxygen supply. The jacket temperature of the calorimeter was raised to $30^{\circ} \mathrm{C}$ 
for $10 \mathrm{~min}$. The head of the calorimeter was loaded and placed into the cylinder. The handle of the lid was rotated clockwise to lock the head into position. The sample weight of $0.5 \mathrm{~g}$ was weighed and put onto the head of the calorimeter. An ignition thread was attached to the sample on top of a solid pellet. The head loaded with the sample was placed into the calorimeter cylinder and was locked. The calorimeter was calibrated by inputting the sample ID, Bomb ID, sample weight and the spike weight. After inputting the figures, the test automatically start by undergoing these cycles which are fill cycle, pre-period cycle, firing cycle, post period cycle, exhaust cycle and cool/rinse cycle. At the end of the test, once the calorimeter is finished with the cool/rinse cycle, the result is displayed and printed out.

\subsection{Survey on the Use of the Cocoa Pod Husks and Mixed Product Briquettes}

\subsubsection{Study Area}

The study was conducted in Sefwi Humjibre, located in the Bibiani-Anwhiaso-Berkwai District in the Western North Region of Ghana. The district has an estimated population of 28,000 of which about $74.9 \%$ are engaged in agriculture [22]. The district shares boundaries with six districts which are Atwima Mponua, Amansie West, Upper Denkyira, Wassa Amenfi East, Wassa Amenfi central and Sefwi Wiawso District. Wood, charcoal and petroleum gas are the main sources of fuel for domestic heating and other commercial activities. About $85 \%$ of the inhabitants rely on wood fuel in the form of firewood and charcoal for heating purposes because they are relatively cheaper [22]. Sefwi Humjibre is one of the largest cocoa producing communities in the district [23]. Apart from cocoa cultivation, other farmers cultivate cash crops such as plantain, cocoyam and maize [22].

\subsubsection{Sampling Technique and Data Collection}

Purposive sampling method was used in the collection of data for the survey on the usage of the briquettes produced. A total of sixty (60) respondents were interviewed which comprised of thirty (30) households and thirty (30) food vendors. Ten (10) out of the thirty (30) household respondents were males and the remaining twenty (20) were females while five of the food vendors, five (5) were males and twenty five (25) were females. Twenty five (25) of the household respondents were cocoa farmers who were within the age range of forty to sixty years, four (4) were government workers (two teachers and two nurses) within the age range of twenty to forty years and the last household respondent was a cocoa farmer and as well a government worker (teacher) within the age range of twenty to forty years. On the other hand, five (5) of the food vendors interviewed were solely into food vending within the age range of twenty to forty years and twenty five (25) of the other food vendors interviewed were also cocoa farmers who were within the age range of forty to sixty years.

Fifteen (15) out of the thirty (30) household respondents were given $5 \mathrm{~kg}$ each 
of the 5 carbonised cocoa pod husk briquette product to use whiles the other fifteen (15) were given $5 \mathrm{~kg}$ each of the mixed product briquette to use. The same quantities were given to the food vendors where fifteen (15) of the respondents were given $5 \mathrm{~kg}$ each of the 5 carbonised cocoa pod husk briquette while the other fifteen (15) respondents were given the mixed product briquette to use. The rationale for the usage analysis was to establish a comparative statistics in relation to the two different types of briquette produced whether they could serve as a substitute to charcoal fuel.

Open and closed ended questionnaires were administered to the users of the produced briquette. The questionnaire had coverage of users' occupations, consumers' preferences on the fuel they use, nature of work and willingness to adopt and use the new briquettes produced.

\subsection{Experimental Design and Data Analysis for Laboratory Analysis}

A completely randomized design (CRD) with 3 replications was used to analyse the proximate, ultimate and calorific values of the briquettes produced at the Kwame Nkrumah University of Science and Technology chemistry department laboratory.

The data collected were subjected to analysis of variance (ANOVA) using Genstat statistical package (Version 12). Treatment means found to be significantly different were separated using least significant difference (LSD) at 5\% probability level or $95 \%$ confidence interval. Statistical data from the survey was analyzed using Microsoft Excel version 2010 software and were summarized in the form of frequency and percentage.

\section{Result and Discussion}

\subsection{Ultimate Analysis}

From Table 1, the percentage nitrogen content of the charcoal produced from the (Terminalia sp.) which was our standard was not significantly different from that recorded for the carbonised cocoa pod husk. The mixed briquette samples recorded the highest nitrogen content of $(7.4 \%)$ at $(\mathrm{P}<0.05)$ which was significantly different from the charcoal and the briquette from the cocoa pod husk samples. The high nitrogen content in the mixed sample could be attributed to the portion of sawdust in the mixed sample which may contain nitrogen bonded compounds such as alkaloids and porphyrins in its untreated state [19]. Chaney [24] reported that percentage nitrogen content in biomass briquettes should not exceed 1\% which is analogous to the percentage recorded for carbonised cocoa pod husk. The percentage nitrogen content obtained for the carbonised cocoa pod husk is welcomed because high levels of nitrogen in fuels could lead to the formation of photochemical smog and also serious respiratory conditions [25].

Percentage hydrogen content of the carbonised cocoa pod husk $(2.5 \%)$ was 
Table 1. Results of ultimate analysis.

\begin{tabular}{cccccc}
\hline Treatments & $\mathrm{N}(\%)$ & $\mathrm{C}(\%)$ & $\mathrm{H}(\%)$ & $\mathrm{S}(\%)$ & $\mathrm{O}(\%)$ \\
\hline Charcoal & $1.1 \mathrm{~b}$ & $57.0 \mathrm{a}$ & $2.6 \mathrm{~b}$ & $0.1 \mathrm{c}$ & $36.3 \mathrm{c}$ \\
$\begin{array}{c}\text { Carbonised cocoa pod } \\
\begin{array}{c}\text { Carbonised cocoa pod + Sawdust } \\
\text { (mixed) }\end{array}\end{array}$ & $1.1 \mathrm{~b}$ & $54.0 \mathrm{~b}$ & $2.5 \mathrm{c}$ & $0.3 \mathrm{~b}$ & $38.9 \mathrm{~b}$ \\
$\begin{array}{c}\text { LSD (0.05) } \\
\text { S.E.D }\end{array}$ & $32.7 \mathrm{c}$ & $5.3 \mathrm{a}$ & $0.5 \mathrm{a}$ & $51.3 \mathrm{a}$ \\
CV (\%) & 0.13 & 0.53 & 0.07 & 0.01 & 0.94 \\
& 0.05 & 0.19 & 0.03 & 0.003 & 0.34 \\
\hline
\end{tabular}

${ }^{*}$ Means with the same letter(s) are not significantly different $(\mathrm{P}>0.05)$ at $5 \%$ probability level. Where Least Significant Difference (LSD), Standard Error of Deviation (S.E.D). Coefficient of Variation (CV).

significantly different from that recorded for charcoal sample which recorded (2.6\%) and the mixed sample (5.3\%). Levels of hydrogen in fuel are very critical because good fuel tends to have low hydrogen content. According to Ryemshak and Aliyu [26] low hydrogen content results in low amount of volatile matter. The high percentage of hydrogen obtained for the mixed sample could be attributed to the portion of sawdust which may contain some level of hydrogen in their natural state. Bourgeois and Doat [27] observed that completely carbonised biomass tend to have a lower hydrogen and volatile matter content which was observed with the carbonised cocoa pod briquette. Even though the content of hydrogen in the mixed briquette sample was higher than the standard charcoal and the carbonised cocoa pod briquette samples, the content was within an acceptable range of $5 \%$ to $6 \%$ as observed by Chaney [24].

Percentage carbon content recorded for charcoal (57\%) was significantly higher than that of both the carbonised cocoa pods husk (54.0\%) and mixed briquette (32.7\%) samples. The high carbon content obtained for the carbonised cocoa pod and the standard charcoal indicates that it will burn fast than the mixed sample because high carbon content in fuel aids combustion [3]. The reason for the lower content recorded for the mixed sample could be attributed to the non carbonised portion of sawdust which was added because the main resulting characteristics of carbonisation of biomass is an increased percentage of carbon [28] which was evident for the percentage recorded for the carbonised cocoa pod husk and our standard charcoal. Even though the results obtained when compared to the standard sample (charcoal) were significantly different from each other, the findings were within an acceptable range as it corroborates with observations made by Chaney [24] who observed that carbon content in biomass are mostly within the range of $30 \%$ to $60 \%$.

Percentage oxygen content recorded for the carbonised cocoa pods husk (38.99\%) was significantly different from both the standard (charcoal) (36.34\%) and the mixed sample (51.31\%) as observed in Table 1. The high oxygen content in the mixed sample could be attributed to the sawdust portion that was added 
which may contain some amount of oxygen in their natural state. According to Bourgeois and Doat [27], non-carbonised biomass tends to have a higher oxygen content than fully carbonised briquettes. Chaney [24] gave a range of 30\% to $40 \%$ as an acceptable range for percentage oxygen in biomass which indicated that the percentage recorded for the carbonised cocoa pod husk was within an acceptable range. Even though percentage oxygen recorded for the mixed sample was high, it was good because high oxygen content in biomass is good for burning [29].

Percentage sulphur content obtained for the carbonised cocoa pod husk $(0.26 \%)$ was significantly different from the standard charcoal $(0.1 \%)$ and mixed sample $(0.49 \%)$. Due to the toxic nature of sulfur when released into the atmosphere, biomass fuel with lower sulphur contents are preferred [30]. Combustion of biomass with high sulphur content leads to the formation of sulphur oxides in the atmosphere which could lead to formation of acid rains [31]. Comparison of the results to literature shows that the percentage Sulphur recorded for the carbonised cocoa pod husk was within an acceptable range because Garcia et al., [32], observed that sulphur content of biomass was within the range of $(0.17 \%$ $0.46 \%)$. The higher Sulphur content for the mixed sample could be attributed to the portion of the non-carbonised portion of sawdust which may contain some amount of Sulphur in its natural state.

\subsection{Proximate Analysis}

From Table 2, the moisture content obtained for charcoal (5\%) was significantly different from that of the mixed sample (4.6\%) and the carbonised cocoa pod husk (5.9\%). Rowell [33] observed that chemical composition including moisture content varies in different parts of plant which was evident in the result obtain for the cocoa pods husk when compared to the charcoal which was derived from a plant stem. Again, cocoa pod husk tends to possess low amount of lignin and high moisture content than wood stems which usually possess high amount of lignin and low amount of moisture [34]. This tends to have an effect on the calorific value as fuels with high moisture content tend to have lower calorific value and vice versa [35].

Table 2. Result of proximate analysis.

\begin{tabular}{ccccc}
\hline Treatments & Ash (\%) & $\begin{array}{c}\text { Moisture } \\
(\%)\end{array}$ & $\begin{array}{c}\text { Fixed carbon } \\
(\%)\end{array}$ & $\begin{array}{c}\text { Volatile } \\
\text { matter (\%) }\end{array}$ \\
\hline Charcoal & $2.9 \mathrm{~b}$ & $5.0 \mathrm{~b}$ & $53.1 \mathrm{~b}$ & $39.0 \mathrm{~b}$ \\
Carbonised cocoa pod & $3.2 \mathrm{a}$ & $5.9 \mathrm{a}$ & $59.5 \mathrm{a}$ & $31.5 \mathrm{c}$ \\
$\begin{array}{c}\text { Carbonised cocoa pod +Sawdust } \\
\text { (Mixed) }\end{array}$ & $2.8 \mathrm{~b}$ & $4.6 \mathrm{c}$ & $41.6 \mathrm{c}$ & $51.0 \mathrm{a}$ \\
LSD (0.05) & 0.18 & 0.26 & 0.70 & 0.51 \\
S.E.D & 0.06 & 0.09 & 0.25 & 0.18 \\
CV (\%) & 3.40 & 2.20 & 0.60 & 0.84 \\
\hline
\end{tabular}

${ }^{*}$ Means with the same letter(s) are not significantly different $(\mathrm{P}>0.05)$ at $5 \%$ probability level. ${ }^{*}$ Least Significant Difference (LSD). ${ }^{*}$ Standard Error of Deviation (S.E.D), ${ }^{*}$ Coefficient of Variation (CV). 
The percentage ash content recorded for the charcoal (2.8\%) was not significantly different from that of the mixed sample (2.9\%) but was significantly different from that of the carbonised cocoa pod husk sample (3.2\%). The low ash content in the charcoal and mixed sample could be attributed to the tree species (Terminalia ivorensis) used and the part of plant used because plant stems tends to possess a low concentration of ash forming elements like calcium, potassium and manganese [36]. The high ash content recorded for the carbonised cocoa pod husk sample could be attributed to the high level of inorganic elements in the husk (calcium, potassium and silicon) which remained after burning [37].

The percentage volatile matter content recorded for charcoal (39\%) was significantly different from that obtained for the carbonised cocoa pod sample (31.5\%) and the mixed sample (51\%). The high volatile matter in the mixed sample could be attributed to the portion of sawdust which contains lignins. Lignins are made up of aromatic compounds with strong bonds of hydroxyl and methoxy-substituted phenyl propane in their structure which makes them difficult to break [38] and the only way lignins can be broken is through pyrolysis [39]. Because the sawdust portion in the mixed sample was not carbonised, it resulted in a partially carbonised sample which possessed some level of condensable vapour, permanent gases and also lignins leading to an increase in the volatile matter content in the mixed sample. Bourgeois and Doat [27] observed that partially carbonised biomass tends to have a high volatile matter content because not all gasses are released during the partial carbonization which results in a high volatile matter content in the biomass after carbonization.

Fixed carbon content obtained for the charcoal sample (53.1\%) was significantly different from that recorded for the carbonised cocoa pods (59.5\%) and also the mixed sample (37.4\%). The low percentage of fixed carbonrecorded for the mixed sample could be attributed to the non-carbonised sawdust which was added to the carbonised cocoa pods.

\subsection{Calorific Value}

From Table 3, the calorific value recorded for our standard charcoal sample $(18.472 \mathrm{MJ} / \mathrm{kg}$ ) was significantly different from the carbonised cocoa pod $(16.731 \mathrm{MJ} / \mathrm{kg}$ ) and also the mixed sample $(23.608 \mathrm{MJ} / \mathrm{kg})$. The low value obtained for the carbonised cocoa pod husk could be attributed to the high moisture content in cocoa pods husk and also low amount of lignins in their natural state. Vyas et al. [40] observed that agricultural residue biomass materials are generally hygroscopic in nature which normally leads to a reduction in calorific value as a result of the low lignins in them. The high calorific value obtained for the mixed sample could be attributed to the high level of lignins in the portion of sawdust which was added to the mixed sample. Ravindranath and Oakley [41] also observed that biomass with high amount of lignin's like sawdust or wood tends to have higher calorific value because of the extractives and bonds that lignin's possess which increases the heating value. 
Table 3. Result of calorific test.

\begin{tabular}{cc}
\hline Treatments & Gross calorific value, $\mathrm{MJ} / \mathrm{Kg}$ \\
\hline Charcoal & $18.5 \mathrm{~b}$ \\
Carbonised cocoa pod & $16.7 \mathrm{c}$ \\
Carbonised cocoa pod + Sawdust (Mixed) & $23.6 \mathrm{a}$ \\
LSD (0.05) & 0.88 \\
S.E.D & 0.32 \\
CV (\%) & 2.0 \\
\hline
\end{tabular}

${ }^{*}$ Means with the same letter $(\mathrm{s})$ are not significantly different $(\mathrm{P}>0.05)$ at $5 \%$ probability level. ${ }^{\star}$ Least Significant Difference (LSD). ${ }^{*}$ Standard Error of Deviation (S.E.D). ${ }^{*}$ Coefficient of Variation (CV).

\subsection{Outcome from Survey}

Results from the survey showed that (85\%) of the respondents were engaged in cocoa farming. The survey further disclosed that a high percentage (94\%) of the respondents used wood fuels or charcoal for their cooking and heating activities. This corroborates Emerhi [2] findings that fuel for rural inhabitants has mainly been wood fuels. This poses a great threat to the environment as more trees need to be felled to meet this high energy demand. The survey also revealed that (98\%) of the respondents were willing to adopt and use the new kind of fuel (briquette) for their daily heating and cooking activities if made available to them. On the smoke level of the briquettes, (66\%) of the respondents were content with the fuel because it did not generate any smoke during combustion whilst (33\%) of the respondent were not content with the smoke emitted during combustion. A critical analysis of the (33\%) showed that, majority of the household respondents who used the mixed sample briquette were not content with the level of smoke that emitted. This could be attributed to the portion of sawdust which was added to the mixed sample. Because the sawdust in the mixed sample briquette was not carbonised, it contained some volatile compounds which were emitted during burning and that resulted in the release of some smoke. Majority of the respondents (90\%) were content with the heat produced by the briquette. Only $10 \%$ of the respondents were not content with the heat produced by the briquette. A further analysis of the (10\%) showed that majority of the respondents were wayside food vendors. They preferred the mixed sample briquette to the carbonised cocoa pod husk briquette because the mixed sample briquette produced the required heat they preferred for their heating activities.

\section{Conclusions}

It can be concluded that, easy to produce, low Sulphur and good calorific value cocoa pod husk briquettes have been produced through carbonisation.

The calorific value obtained for the carbonised cocoa pod husk briquette sample was good and suitable for domestic cooking and heating activities when compared with our standard charcoal sample. Sulphur content of the carbonised cocoa pod husk briquette was very low and therefore poses no threat to the en- 
vironment. The cocoa pod husk and sawdust mixed briquettes produced, though showed good calorific value, the volume of smoke produced by this product makes it less preferred by users to the pure cocoa pod husk briquette. The technique for the briquette production can easily be adapted by the cocoa farmers so as to add value and increase income from this biomass which is considered waste and left on cocoa farms to rot.

Results from the survey showed that majority of the respondents are willing to change from the use of firewood and use the briquette if it becomes available to them. This switch from the use of firewood and charcoal will help reduce the rate of deforestation.

\section{Conflicts of Interest}

The authors declare no conflicts of interest regarding the publication of this paper.

\section{References}

[1] Goswam, D.Y. and Kreith, F. (2007) Global Energy System. In: Handbook of Energy Efficiency and Renewable Energy, Taylor and Francis Group, LLC, Boca Raton, FL, 1-20. https://doi.org/10.1201/9781420003482.ch1

[2] Emerhi, E.A. (2011) Physical and Combustion Properties of Briquettes Produced from Sawdust of Three Hard Wood Species and Different Organic Binders. Advances in Applied Science Research, 2, 236-246.

[3] Akowuah, J.O., Kermausuor, F. and Mitchual, S.J. (2012) Physico-Chemical Characteristics and Market Potential of Sawdust Charcoal Briquette. International Journal of Energy and Environmental Engineering, 3.

https://doi.org/10.1186/2251-6832-3-20

[4] Phonphuak, N. and Thiansem, S. (2012) Using Charcoal to Increase Properties and Durability of Fired Test Briquettes. Construction and Building Materials, 29, 612-618. https://doi.org/10.1016/j.conbuildmat.2011.11.018

[5] Amaya, A., Medero, N., Tancredi, N., Silva, H. and Delana, C. (2007) Activated Carbon Briquettes from Biomass Materials. Bioresource Technology, 98, 1635-1641. https://doi.org/10.1016/j.biortech.2006.05.049

[6] Suhartini, S., Hidayat, N. and Wijaya, S. (2011) Physical Properties Characterization of Fuel Briquette Made from Spent Bleaching Earth. Biomass Bioenergy, 35, 4209-4214. https://doi.org/10.1016/j.biombioe.2011.07.002

[7] Wilaipon, P. (2007) Density Equation of Bio-Coal Briquettes and Quantity of Maize Cob in Phitsanulok, Thailand. American Journal of Applied Sciences, 5, 1808-1811. https://doi.org/10.3844/ajassp.2008.1808.1811

[8] Ghana Statistical Service (2014) Ghana Living Standard Survey Round 6 (GLSS6).

[9] Trossero, M.A. (2002) Wood Energy: The Way Ahead. Unasylva, 53, 3-12.

[10] The Cocoa Barometer (2018). https://cocoainitiative.org/knowledge--centre-post/cocoabarometer2018

[11] Richard, A., Martina, F.B. and Edward, A. (2011) Biogas as a Potential Renewable Energy Source: A Ghanaian Case Study. Renewable Energy, 36, 1510-1516. https://doi.org/10.1016/j.renene.2010.11.012

[12] Ghana COCOBOD Website. https://www.cocobod.gh 
[13] Ofori-Boateng, C. and Teong-Lee, K. (2013) The Potential of Using Cocoa Pod Husk as Green Solid Base Catalyst for the Trans-Esterification of Soybean Oil into Biodiesel: Effect of Biodiesel on Engine Performance. Chemical Engineering Journal, 200, 395-401.

http://www.sciencedirect.com/science/article/pii/S1385894713000867 https://doi.org/10.1016/j.cej.2013.01.046

[14] Cocoa Forest Initiative, COP23. https://www.worldcocoafoundation.org/cocoa-forests-initiative/

[15] Kuti, A.O. (2011) Performance of Composite Sawdust Briquette Fuel in a Biomass Stove under Simulated Condition.

[16] Aphonse, N., Ekise, I. and Alphonsine, M. (2012) Comparative Study of Charcoal Yield Produced by Traditional and Improved Kilns: A Case Study of Nyaruguru and Nyamagabe Districts in Southern Province of Rwanda.

[17] Nelson, D.W. and Sommers, L.W. (1982) Total Carbon and Organic Matter. In: Page, A.L., Miller, R.H. and Keeney, D.R., Eds., Methods of Soil Analysis Part 2, 2nd Edition, No. 9, American Society of Agronomy, Soil Science of America, Madison, WI.

[18] Bremner, J.M. and Mulvaney, C.S. (1982) Nitrogen-Total. In: Page, A.L., Miller, R.H. and Keeney, D.R., Eds., Methods of Soil Analysis. Part 2, Agronomy 9, 595-624.

[19] Adekunle, J.O., Ibrahim, J.S. and Kucha, E.I. (2014) Proximate and Ultimate Analysis of Biocoal Briquettes of Nigerians Ogboyaga and Okaba Sub-Bituminous Coal. Current Journal of Applied Science and Technology, 7, 114-123. https://doi.org/10.9734/BJAST/2015/15154

[20] Speight, J.G. (2005) Hand Book of Coal Analysis. Chemical Analysis: Series of Monographs on Analytical Chemistry and Applications. John Wiley and Sons, Hoboken, NJ, 222.

[21] Omoniyi, T.E. and Olorunnisola, A.O. (2014) Experiment Characterization of Bagasse Biomass Material for Energy Production.

[22] Ghana Statistical Service (2014) Population and Housing Census, District Analytical Report 2010 (Sefwi Bibiani-Anwhiaso Berkwai District).

[23] Produce Buying Company (2018) Awaso District.

[24] Chaney, J. (2010) Combustion Characteristics of Biomass Briquettes. University of Nottingham, Nottingham.

[25] Silman, S. (2003) Tropospheric Ozone and Photochemical Smog [Chapter 11]. In: Sherwood Lollar, B., Ed., Treatise on Geochemistry. Environmental Geochemistry, Elsevier, Amsterdam. https://doi.org/10.1016/B0-08-043751-6/09053-8

[26] Ryemshak, S. and Aliyu, J. (2014) Proximate Analysis, Rheological Properties and Technological Applications of Some Nigeria Coals. International Journal of Industrial Chemistry, 4, 1-7. http://www.indstchem.com https://doi.org/10.1186/2228-5547-4-7

[27] Bourgeois, J.P. and Doat, J. (1985) Torrefied Wood from Temperate and Tropical Species; Advantages and Prospects. In: Bioenergy, Volume, III, Elsevier, New York, 153-159.

[28] Obernberger, I. and Thek, G. (2004) Physical Characterization and Chemical Composition of Densified Biomass Fuels with Regard to Their Combustion Behaviour. Biomass \& Bioenergy, 27, 653-669.

https://doi.org/10.1016/j.biombioe.2003.07.006 
[29] Nag, P.K. (2002) Power Plant Engineering. 2nd Edition, McGraw-Hill Publishing Company Limited, New Delhi, India, 876.

[30] Meng, X. (2012) Biomass Gasification; The Understanding of Sulphur, Tar and Char Reaction in Fluidized Bed Gassifiers.

[31] Roy, P. and Sarder, A. (2015) $\mathrm{SO}_{2}$ Emission Control and Finding a Way Out to Produce Sulphuric Acid from Industrial $\mathrm{SO}_{2}$ Emission. Journal of Chemical Engineering and Process Technology, 6, 230.

[32] García, R., Pizarro, C., Lavín, A.G. and Bueno, J.L. (2012) Characterization of Spanish Biomass Wastes for Energy Use. Bioresource Technology, 103, 249-258. https://doi.org/10.1016/j.biortech.2011.10.004

[33] Rowell, R.M., Han, J.S. and Rowell, J.S. (2000) Characterization and Factors Effecting Fiber Properties. In: Frollini, E., Leão, A.L. and Mattoso, L.H.C., Eds., Natural Polymers and Agrofibers Composites, Sãn Carlos, Brazil, 115-134.

[34] Zawawi, D., Angzzas, S.M.K., Halizah, A. and Mohd, Z.M.H (2013) Chemical Composition and Morphological of Cocoa Pod Husk and Cassava Peels for Pulp and Paper Production.

[35] Aina, O.M., Adetogun, A.C. and Iyiola, K.A. (2009) Heat Energy from Value Added Sawdust Briquette of Albiziazygia. Ethiopian Journal of Environmental Studies and Management, 2, 42-49. https://doi.org/10.4314/ejesm.v2i1.43501

[36] Liang, W. and Janka, D. (2014) Characterisation of Ashes from Different Wood Parts of Norway Spruce Tree.

[37] Platace, R. and Adamovics, A. (2012) Energy Crop Pellet Combustion Ability. Research for Rural Development, Jelgava, 50-55.

[38] Glasser, W.G. and Sarkanen, S. (1989) Lignin: Properties and Materials. American Chemical Society, Washington DC. https://doi.org/10.1021/bk-1989-0397

[39] Kawamoto, H. (2017) Lignin Pyrolysis Reaction. Journal of Wood Science, 63, 117. https://doi.org/10.1007/s10086-016-1606-Z

[40] Vyas, D.K., Sayyad, F.G., Khardiwar, M.S. and Kumar, S. (2015) Physicochemical Properties of Briquettes from Different Feedstock. Current World Environment, 10, 263-269. https://doi.org/10.12944/CWE.10.1.32

[41] Ravindranath, N.H. and Oakley, H.D.H. (1995) Biomass, Energy and Environment: A Developing Country Perspective from India. Oxford University Press, Oxford. 